\title{
ВЕЛИГДЕНСКИ ПРАЗНУВАЊА: ТРАДИЦИЈА И СОВРЕМЕНОСТ
}

Апстракт: Велигденските празнувања заземаат посебно место на целиот македонски ареал. Се празнува три дена. Првиот ден е наменет за одење во црква и посетување на починатите, вториот ден Велигден се изведува литија, се носат крстови, се пеат наменски песни во кои се моли Господ за благосостојба и се посетуваат светите места. Третиот ден се одржуваат собори, каде што со песни и танци се слави Велигден. Во западномакедонските пејачки традиции велигденските песни се делат на песни што се пеат за време на постите, песни што се пеат на празникот Велигден и песни што се изведуваат првата недела по Велигден. Во текот на велигденските празнувања, се пеат песни што содржат многу митолошки елементи, чиишто корени се протегаат до далечното минато кога човекот верувал во постоењето на разни натприродни сили и суштества, како што се чумите, ламјите и самовилите, кои владееле со природата и со човекот. Подоцна, за време на христијанството, овие суштества од народната митологија во велигденските песни се заменети со светци, карактеристични примери за источномакедонските обредно-пејачки традиции. Во нив се пее за самиот празник и празнување и тие примиле повеќе христијански обележја од понови времиња, па така во нив е очигледна контаминацијата на различни слоеви - пагански и христијански.

Клучни зборови: Велигден, празнувања, собори, обичаи, обреди, песни и обредни игри.

Велигден е најстариот празник на христијанската црква и не е врзан за одреден датум. Се празнува три дена, а првиот ден секогаш се паѓа во недела и тоа првата недела по полната месечина и пролетната рамнодневица (Дробњаковић, 1960, 153). Во комплексот на овие празнувања голем број елементи се задржале уште од претхристијанскиот период и претставуваат јасен одглас на далечниот пагански период. Подоцна христијанството, увидувајќи дека навиките на народот не можат така лесно да се менуваат и да се потиснат, истите тие навики ги усвоило и ги прилагодило спрема своите потреби ${ }^{1}$.

Велигденските празнувања заземаат посебно место на целиот македонски ареал. Од минатото до денес е обележан со бројни обичаи, обреди и песни. За овие празнувања луѓето се подготвуваат во текот на седум недели (седмици) - од почетокот на велигденските пости до самиот празник. Таа подготовка се состои од физичка и од духовна пурификација за да се биде чист на тој голем празник, што подразбира да не се јаде мрсна храна, односно се држат строги пости, така што храната што се внесува во организмот е само од

\footnotetext{
${ }^{1}$ В. Кличкова, проучувајќи ги велигденските обичаи во Порече, смета дека бројни елементи кај нив се задржале од старите антички празници наречени Големи Дионизии, односно празници посветени на богот Дионис, богот на виното и плодородието (Кличкова, 1957, 153).
} 
растително потекло. Но, главните подготовки започнуваат една недела пред Велигден: се чистат домовите и се вапсаат јајца, ${ }^{2}$ при што се изведуваат разни обредни дејства, кои се поврзани со здравјето и плодноста на луѓето и добитокот. Се празнува три дена. Првиот ден е наменет за одење во црква и посетување на починатите, вториот ден Велигден се изведува литија, се носат крстови, се пеат наменски песни во кои се моли Господ за благосостојба и се посетуваат светите места. Третиот ден се одржуваат собори, каде што се слави Велигден со песни и со ора.

Во западномакедонските пејачки традиции велигденските песни се делат на песни што се пеат за време на постите, песни што се пеат на празникот Велигден и песни што се изведуваат првата недела по Велигден (Целакоски, 1984, 136).

Во текот на велигденските празнувања се пеат песни, кои содржат многу митолошки елементи (Пенушлиски, 1968, 12), чиишто корени се протегаат до далечното минато кога човекот верувал во постоењето на разни натприродни сили и суштества, како што се чумите, ламјите и самовилите, кои владееле со природата и човекот. Во мотивите од овие песни тие натприродни сили и суштества често се спомнуваат како добри и како зли, како што е прикажано во песната: „Црква прави самовила/ Ни на небо, ни на земја/ туку-така под облака...“ (Видете го примерот број 1) или како во песната: „Го врзале Марка вили, самовили“, карактеристичен пример за Демирхисарскиот Регион (Видете го примерот број 2).

Подоцна, за време на христијанството, овие суштества од народната митологија во велигденските песни се заменети со светци. Таков е случајот со песната за „Богда́н-чорбаџијата“, кој орал на прв ден Велигден, во која, преку дијалошка постапка меѓу облаците му се изрекува казната:

$$
\begin{aligned}
& \text { - Да удреме селаните? } \\
& \text { - Не са криви села́ните! } \\
& \text { - Да удреме две му ќерки? } \\
& \text { - Ништо Бог да́ не позна́ва! } \\
& \text { - Ке удреме два му сина, } \\
& \text { тога́ј Богда́н ќе позна́е, } \\
& \text { ќе излезат до две снаи... }
\end{aligned}
$$

Ова е карактеристичен пример на песна за источните обредно-пејачки традиции, поточно, е распространета во Малешевско-пијанечкиот, Радовишкиот, Штипскиот и Овчеполскиот Регион. (Видете го примерот број 3). Во ваквите песни се пее за самиот празник и празнувањето. Тие примиле повеќе христијански обележја од понови времиња, па така во нив е очигледна

2 Вапсањето („шарањето“) јајца е многу стар обичај. Познат е уште кај старите Словени и старите Германи, а вапсани јајца се пронајдени и во старите скандинавски гробишта (Кличкова, 1957, 156).

${ }^{3}$ АИФ м.л. бр. 2705, с. Пиперово, Штипско (1979). 
контаминацијата на различни слоеви - пагански и христијански (Китевски, 1997, 60).

Велигденските празнувања во Охридско-струшкиот Регион заземаат посебно место во верскиот календар. Тие се проследени со велигденски песни, кои, во овој регион се пеат во текот на трите дена од празникот, од кои повеќето се исполнуваат на оро и се викаат „ороводни песни“.

Од истражувањата на Кличкова дознаваме дека жените во Струга, на помалите празници и од своите маала оделе две по две кон соборот, распоредувајќи се една по друга во колце или како тие го викаат „на танец“начин на играње на оро, со кружно распоредување на играчите, при што не се поврзани „танчаријата“ и „опашката“ (Кличкова, 1957, 162-168). Всушност тие вршат еден ритуал без кој не може да биде отворањето на велигденскиот собор. Соборот, истакнува Кличкова, го обиколуваат кроткум до 3 пати, пеејќ. Првите две жени што го зазбируваат орото се викаат „танчарии“, а последните две - „опашка“. Обично танчариите се жени, кои, во селата од целиот Струшки Регион, се познати како добри игроорки и добри песнопојки. Значи, жените или девојките, фатени во обредното оро, ги изведуваат песните антифоно: најнапред започнуваат да пеат првите две девојчиња, а потоа настапуваат другите две, па третите, во зависност од бројот на учесничките во обредното оро, кое често се спомнува и во самите стихови на овие песни:

Сино езеро оро градено, $\underline{\text { !! }}$ го заградиле на ден Велигден, до полу дошле на ден Ѓ урѓовден, го доградиле на ден Спасовден. ${ }^{4}$

Посебно драгоцени се кажувањата на Цара Чочоска од с. Радожда, Струшко, во врска со тридневните велигденски празнувања. Така на пример, на првиот ден од Велигден, жените одат в црква, носат јајца и таму играат и ја пеат песната:

Света Недела доз, и!, цркви метеше, доз, и! ем солзи рони, доз, и!,, 5

(Видете го примерот бр. 5),

а на вториот ден ја пеат песната:

- Калуфере, ситен дробен, доз, доз, што не растиш да порастиш!

\footnotetext{
${ }^{4}$ АИФ, касета бр. 3909. Пее: Спаса Поповска од с. Ложани, Струшко. (Видете го примерот број 4).

${ }_{5}^{5}$ АИФ, касета бр. 3982. Пеат: Цара Чочоска, Ангелина Грческа и Јорда Скерческа од с. Радожда, Струшко; „наизвишвање“.
} 
(Видете го примерот бр. 6).

Како што може да се забележи, велигденските празнувања со обредна игра и песна се опејувани често, што зборува за една сѐ уште сочувана традиција од овој регион, особено карактеристична за селото Радожда (Струшко), кое претставува еден од крајните пунктови на македонскоалбанската граница, а кое се одликува со уникатност по сочуваноста на обредот и на обредното пеење (Величковска, 2006, 143-185).

На последниот ден од празникот, карактеристично за овој регион, е тагувањето на жените по празникот, бидејќи за цело време на празнувањето играат и се веселат, речиси и без да забележат дека празникот веќе изминува. Сето тоа, во форма на дијалог меѓу момата и „Велигден“ - сликовито е изразено преку стиховите:

- Велигден, море Велигден да кога дојде и појде, со нога не те игравме, со уста не те пеавме, со очи не те видовме, со пусти алаулиња!

- Моме ле, море, моме ле, три дни ме носи на појас, три дни ме гази под нозе, црвени јајца кршевте, на гајдаџија дававте, кога суи оро игравте. - Велигден, море Велигден, в година пак да ни дојдиш, со китка ќе те чекаме, во десна рака со китки, во лева со јајце!

(Целакоски, 1984, 170-171)

Слична според структурата на текстот ја среќаваме и песната „Леле, леле, Велигден, кога дојде и помина“, испеана од Петра Трајкова (1933) од с. Рожден, Кавадаречко (Видете го примерот број 7).

Велигденските празнувања во Мариовско се проследени со бројни велигденски песни. Милан Ристески, во далечната 1960 година, во списанието „Стремеж“, во рубриката „Документи“, објавил 23 велигденски песни од Мариовско. Песните се делат на три групи: песни што се пеат наутро, напладне и навечер. Девојките, фатени на оро, пеат и играат. Пеат две по две: најнапред почнуваат девојките на челото, а завршуваат тие што се на крајот. Се танцувало само со песни, а не со музика (свирка). ${ }^{6}$

Во Поречкиот Регион велигденските празнувања се проследени со многу „велигденечки“ песни и игри, кои се пеат и се играат во текот на трите дена од празникот. Од истражувањата на Вера Кличкова дознаваме дека на првиот ден на Велигден девојките пеат пригодни песни за истерување на добитокот на пасење, како на пример песната:

\footnotetext{
6 Меѓу песните во збирката, чиј број е прилично голем, велигденскиот мотив е прилично застапен, како на пример: „Оро ми играле триста самовили“, типичен за западниот музичко-дијалектен ареал (Видете во: Стремеж, бр. 6, песна бр. 1) (Ристески, 1960, 55-60; 1960, 56-69).
} 
Сви овчари потерале, дос, и!

Стојан овчар не потера,

туку врти врто село,

врто село Катраново,

За девојка Катрановка.

- Ој, Стојане млад овчаре,

не се л'жи по девојки!

(Кличкова, 1957, 162)

Исто така, на првиот ден Велигден, истакнува Кличкова, дека веднаш по ручекот се „зазбирува собор“, пред црква и сретсело. Собирот го зазбируваат помлади жени, невести и девојки. За отворањето на соборот тие ги пееле велигденските песни: „Собери оро кадан Тодоро“, „Лоза, Лозана, добра девојко“, „Платно ткаеше Јанина мајка“, „Прошетала ми Калина“, „Пленил Ѓуро две sемни босначки“, „Дошол ми дошол војвода, кај Златеица невеста“, „Што е она во Леѓена града“, „Карала Мара свекрва“ и „Што е она на бојно Косово“. Покрај овие велигденски песни, по зазбирувањето, се пееле и многу други, според Кличкова. Карактеристично за велигденските песни е тоа што се пеат „на високо“ - велигденечки“, со икање. За време на велигденските празници, приквечер, кога веќе соборот треба да се растури, девојките ги пееле ороводните песни: „Родила ми се лепа Марија“, „Разиграло се јаболко“, „Пила Неда ноќна вода“" и други (Кличкова, 1957, 162).

На третиот ден од Велигден, истакнува Кличкова, населението во Поречкиот Регион традиционално, со песни и игри, го испраќаат Велигден исто како и кога го дочекуваат првиот празничен ден. Попладне, покрај велигденските ороводни песни се играле и други друштвени игри, кои, во народот се познати како „гачки“, како на пример: Кален број, мален број; Лази ми, лази, бубале; Вили самовили, Змија, Маски, Шутарчиња, Пилци, Благо месо, Јунции и многу други (Кличкова, 1957, 179-200), кои, според содржина се различни игри, специфични според формата на изразување, кои содржат драмски елементи.

Во своите истражувања Катерина Петровска-Кузманова прави реконструкција на обредните игри од Порече (Петровска-Кузманова, 2013, 140-43), кои, како форми на изразување, се слични по структура на целиот македонски ареал, а кои, според народните пејачки, се именувани како ороводни пејачки форми, во кои, на некој начин е застапена форма на организирано движење, проследено со песна. Поголемиот број песни се изведуваат на оро и се нарекуваат „оречки (ороводни) песни - што се тргаат на оро“7 . Така, на пример, народната пејачка Таса Аврамовска-Трајчева, родена во 1910, во с. Крапа, Прилепско, сликовито ни го претстави обредното играње и пеење за време на празнувањата на: Божиќ, Водици, Велигден, Дуовден (Духови) и други празници во селото и пеењето на ороводната песна:

\footnotetext{
${ }^{7}$ Терминологија што се користи во Западното музичко-дијалектно подрачје.
} 


\section{Ѓуро Маро, твојот брато киди/2 \\ Гууро Маро, Турци го сустреле/2 \\ Гуро Маро, пешкиш му го зеле/2 \\ Ѓуро Маро, сребрен копец зеле/2 \\ Ѓуро Маро, ал шамија зеле/2.}

(АИФ м.л. бр. 1263, с. Долгаец, Прилепско, 1970 год.)

Оваа песна се пеела на сретсело, во оро. Карактеристично за неа е тоа што по отпејувањето „Ѓууро Маро“, девојките фатени во орото, чукале со дланките. И откако првите две девојки на танецот ќе отпееле, оделе на опашката од орото, и така со ред дури да се заврши песната. Додека девојките пееле и го играле орото, две девојки стоеле покриени со шамија, го жалеле Ѓуро, што укажува на траги од велигденската игра „Ѓуро Маро Вележано“, како дел од поречките игри, кои ги реконструирала Вера Кличнова. Исто така, сличност со велигденската игра „Калем број, малем број“ од Кличкова среќаваме и од теренските истражувања во с. Бабино, Демирхисарско, во 1966 година, насловена како „Калемчица, малемчица/ калем број, малем број!“ (Видете го примерот број 8). Карактеристично при изведбата на велигденските обредни игри и песни во Демирхисарско е кога девојките играат во две ора и „се наткладуваат“, односно девојките од едното оро маскираат една девојка во машко и сакаат да го земат најубавото девојче од другото оро, и обратно (Величковска, 2008, 158).

Слична по структура на велигденските игри од Кличкова е велигденската ороводна песна „Сега да видиме која поле била“, снимена во с. Жван, Демирхисарско, во 1966 година. Се пее кога девојките играат две ора и се „надкладуваат“, односно девојките од едното оро се маскираат (една девојка ја прават машко) и сакаат да го грабнат најубавото девојче од другото оро, и обратно, пеејќк:

- девојки од првото оро:

Сега да видиме која поле била

Која поле била, која метил пасла,

Која метил пасла во копривје расла

Васка поле била во копривје расла.

- девојки од второто оро:

- Ви го зедовне, ви го зедовне најубото моме! ...

(Видете го примерот бр. 9).

Исто таква сличност забележуваме и кај велигденските женски обредни поворки во Гевгелиско, проследени со обредни игри, како на пример играта „Ѓуура Мара“.

Крале п'рта́ле, крале п'рта́ле, 
песната:

Слушам поите нија вика́аме,

зашо́ вика́ате кој шо ќе врве...

Собра́ле ми се набра́ле.
На ар'мијско кладѐнче.
Таму се сите собра́ле,
Стоја́н не сака да оде,
мајка му не си го пушта...

како и песната:

Младѐне, Младѐне, Млади невојво̀до...

(АИФ, м.л. бр. 2709, с. Миравци, Гевгелиско. Видете го примерот бр. 10).

Сите овие примери, слични по структура на музичко-поетските текстови, упатуваат на една силно развиена ороводно-пејачка традиција во минатото, чии одгласи ги наоѓаме денес, кај младите интерпретаторки, членови на КУД „7 Септември“ од Македонски Брод, кои на автентичен начин ја прикажуваат поречката игра „Каленчица“ на фестивалите низ Републиката и во светот“ (Видете во прилогот: Илустрации, фотографија, број 1 и 2).

Посебно треба да се истакне дека на програмата на Ансамблот „Македонија“, во кој членуваат студенти од Музичката академија при Универзитетот „Гоце Делчев“ во Штип, се застапени поречките игри: „Маски“, „Змија“ и „Шетлика-метлика“ - реконструкција од видеозаписот на Вера Кличкова од далечната 1968 година (Видете во прилогот: Илустрации, фотографија, број 3).

Вклученоста на жената во колективниот живот на заедницата и нејзината меморија на пренесување на музичко-фолклорните форми од генерација на генерација го создала и го оформила нејзиниот модел на пројавување и огласување. Жената е носител на традицијата и нејзината улога е чувар на традицијата, а се истакнува преку големиот број ритуални чинови што ги негува таа. Доминантната улога на жената се состои во: организирањето, раководењето и исполнувањето на традиционалните обреди, почнувајќи од почетокот на големите велигденски пости, па сѐ до завршетокот на аграрната година. Преку оралната трансмисија упатуваат на времето и на просторот кога и каде се изведуваат обичаите, користејќи ги притоа своите специфични интерпретаторски способности (Величковска, 2014, 329).

\section{ЛИТЕРАТУРА}

ВЕЛИЧКОВСКА, Р. (2014). Жената како стожер на обредната пејачка традиција во Македонија и Србија, Конзулска Битола и историските, современите и идните културни и уметнички врски меѓу Р. Македонија и Р. Србија (Зборник на трудови од Меѓународниот научен собир), Конзулат на Р. Србија во Р. Македонија, Битола. 
ВЕЛИЧКОВСКА, Р. (2006). Женското обредно пеење во Охридско-струшкиот регион. Современата состојба на фолклорот во Охридско-струикиот регион. Скопје: Институт за фолклор „Марко Цепенков“, Посебни изданија, кн. 63, Скопје, стр. 143-185.

ВЕЛИЧКОВСКА, Р. (2008). Музичките дијалекти во македонското традииионално народно пеење (Обредно пеење). Македонско народно творештво, Народни песни, Книга 17, Скопје: Институт за фолклор „Марко Цепенков“".

ВЕЛИЧКОВСКА, Р. (2012). Ороводните песни и нивната територијална дистрибуција во македонското традиционално обредно-пејачко изразување. Yearbook - Faculty of Music Art, Vol. 3, No 1 (2012), стр. 149-154.

ДРОБНАКОВИЋ, Б. (1960). Етнологија народа Југославије, први део, Београд. КИТЕВСКИ, М. (1997). Македонска народна лирика: Обредни песни. Култура. КЛИЧКОВА, В. (1957). „Велигденските обичаи во Порече“. Гласник на Музејско-конзерваторското друштво на НРМ, Скопје.

НИКОЛОВ ТЕОХАРОВ, А. (2000). Малешевски народни песни. Скопје: НИП „Студентски збор“.

ПЕНУШЛИСКИ, К. (1968). Обредни и митолошки песни. Скопје.

ПЕТРОВСКА-КУЗМАНОВА, К. (2013). „Велигденски игри од Порече во фолклористичките истражувања“. 105 години од раѓањето на Јозеф Обрембски. Прилеп: Институт за старословенска култура.

РИСТЕСКИ, М. (1960). „Велигденски обичаи и песни во Мариовскиот крај“, Стремеж, бр. 5 и 6. Прилеп.

ЦЕЛАКОСКИ, Н. (1984). Дебариа: Обреди, магии и обредни песни. Скопје: НИП „Студентски збор“.

Rodna Velichkovska

\section{EASTER CELEBRATIONS: TRADITION AND MODERNITY}

\section{Summary}

Easter celebrations take a special place in the entire Macedonian area. They celebrate three days. On the first day people go to church and visit the graves of the deceased, while on the second day of Easter there is a cross procession, during which songs are sung in which the participants pray to the Lord for prosperity and eventually visit the sacred places. On the third day there are gatherings celebrating Easter with songs and dances. Easter songs in Western Macedonian singing traditions are divided into songs sung during the Lent, songs sung at Easter and songs performed the first week after Easter. During Easter, songs are sung that contain many mythological elements whose roots go back to the distant past when man believed in the existence of various supernatural powers and beings, such as plague, dragons and fairies, who ruled nature and man. Later, during Christianity, these creatures of folk mythology in Easter songs were replaced with the saints, which are typical examples of Eastern Macedonian ritual-singing traditions. They sing about the holiday and the celebration itself, and they have received more 
Christian symbols of recent times, so the contamination of various layers - pagan and Christian - is evident in them.

\section{Прилог \\ Нотни и текстуални примери}

\section{1. Црква прави самовила}

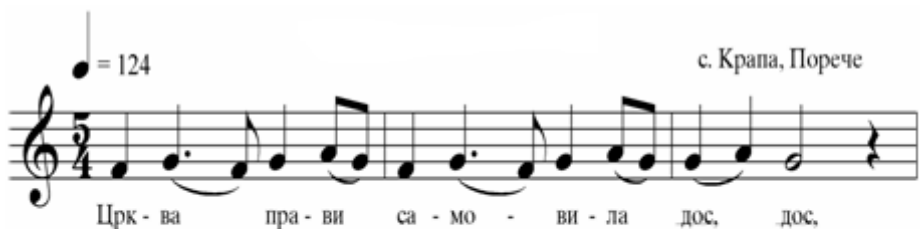

Црк- ва пра - ви са - мо - ви - ла дос, дос,

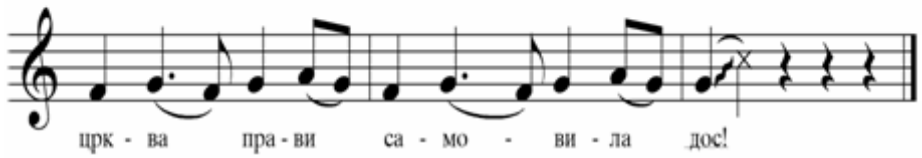

Црква прави самовила, дос дос

sидиштата со дечиња, црква прави самовила, дос. чатисало со јергење, калосало со старички,

Ни на небо, ни на земја, туку-така под облака.

Темелите се со старци, ја покриле со невести, диреците од јунаци, пенџериња со девојки.

АИФ м.л. бр. 1068, с. Крапа, Порече (1969). Пее Паца Јоноска (1905), родена во с. Крапа, Порече. Снимил и дешифрирал Милан Ристески; мелографирала Родна Величковска (Р. Величковска, Музичките дијалекти..., стр.161, песна број 60)

\section{2. Го врзале Марка вили самовили}
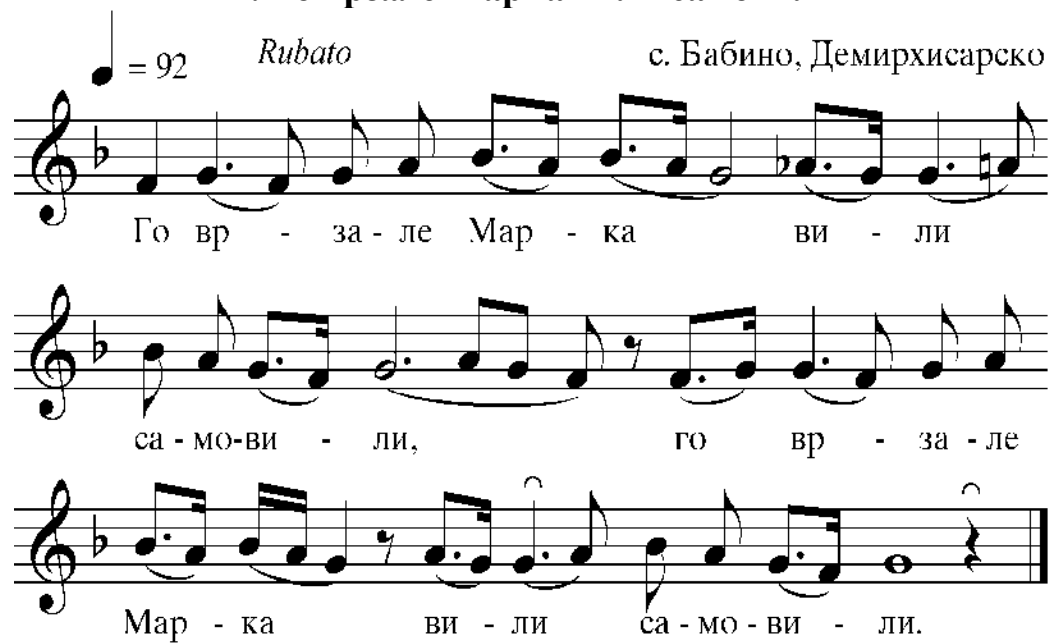
Го врзале Марка вили самовили х2 Му врзале Марка раце наопаку.

По Марка трчаше неговата сестра, по Марка трчаше верно се молеше: - Вили самовили, простете му Марку ја за Марка давам моје бело руво.
По него трчаше Марко́ијо татко, по ними трчаше, верно се молеше: - Вили самовили, простете му Марку, ја за Марка давам волој со се́ рало. Проклетите вили неќат да го пуштат.

АИФ м.л. бр. 473, с. Бабино, Демирхисарско (1966 г.). Пее: Нове Касаповски. Снимил Ганчо Пајтонџиев, дешифрирала Милка Здравева, мелографирал Михајло Димовски. Во: Музичките дијалекти..., стр.167, песна број 58.

\section{3. Богда́н збира села́ните}

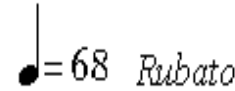

с. Пиперево, Штипско

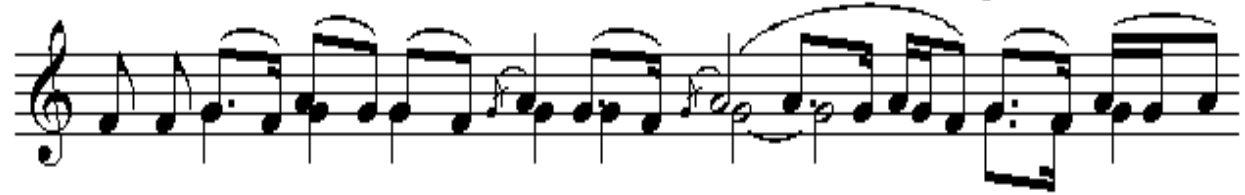

Мо-ри Бог - дан зби - ра се - ла - ни - те,

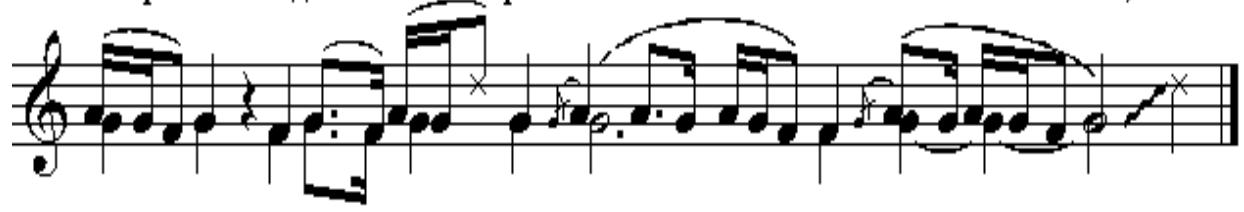

Бог - дан (ан)зби-ра! се - ла - си - те,

II!

Мори, Богдан збира селаните, Богдан (ан) збира селаните, и! Пред Велйгден, Вел четврто́к, да му орат ангарѝја.

Две му снаи мливо сејат, две му ќерки платно белат, два му сина лозје кројат. Зада́ле се двај облака, еде́н темен, други воден, меѓу себе зговор чинат.

- Да удреме селаните?

- Не са криви села́ните!

- Да удреме две му ќерки?

- Ништо Богда́н не позна́ва!

- Ке удреме два му сина, тога́j Богда́н ќе позна́е, ќе излезат до две снаи...

АИФ м.л. бр. 2705, с. Пиперово, Штипско (1979). Пеат Гана Крстева, родена во с. Рачица, Штипско (1916) и Дилбера Нацева, родена во с. Ново Село, Штипско (71). Снимил Ѓорѓи Ѓорѓиев, дешифрирала и мелографирала Родна Величковска. Во: Р. Величковска, Музичките дијалекти..., стр.168, песна број 70. 


\section{4. Сино езеро оро градено}

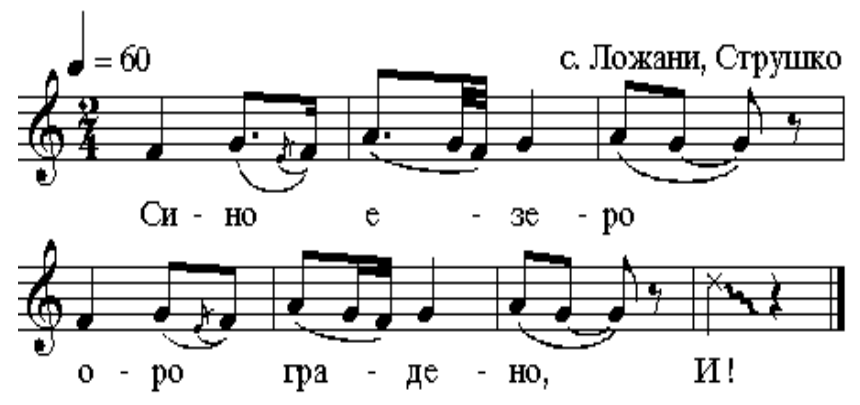

Сино езеро оро градено

Го заградиле на ден Велигден, до полу дошле на ден Ѓ урѓовден, го доградиле на ден Спасовден.

АИФ, касета бр. 3909, с. Ложани, Струшко (2002). Пее Спаса Поповска од с. Мороишта, Струшко. Снимила, дешифрирала и мелографирала Родна Величковска. Велигденска ороводна песна, во: Музичките дијалекти..., стр. 167, песна број 68.

\section{5. Света Недела цркви метеше}

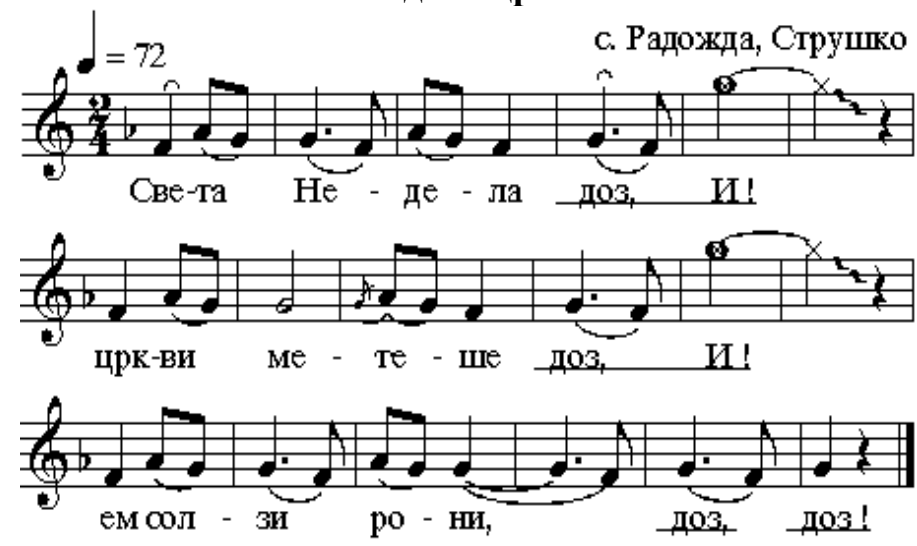

Света Недела доз, и!, цркви метеше, доз, и! ем солзи рони,доз, и!

Ми е догледа Свети Никола:

- Шо сестро метиш ем солзи рониш!

- Как да не мета, как да не плача, оката сребро килото жито! Старите луѓе песок зобаја, 
младите луѓе пепел макајет, ситните деца песок зобаје!

АИФ, касета бр. 3982, с. Радожда, Струшко (2003). Пеат Цара Чочоска (75), Ангелина Грческа (66) и Јорда Скерческа (77) од с. Радожда, Струшко. Снимила, дешифрирала и мелографирала Родна Величковска. Велигденска ороводна песна, во: Р. Величковска, Картографирањето..., стр. 112, песна број 63.

\section{6. Калуфере, ситен дробен}

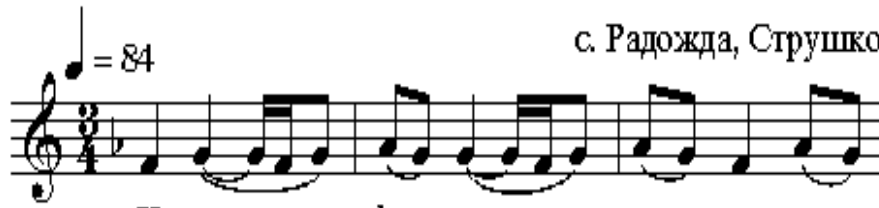

$\mathrm{Ka}$ - sy - de - pe,

си - тен дро -

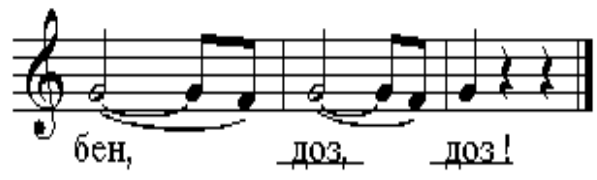

- Калуфере, ситен дробен, доз, доз,

што не растиш да порастиш!

- Как да растам да порастам!

Поминаја „Чесни крсти“,

Чесни крсти „Ристосови“,

Ристосови - Велигденски!

Поминаја ме згазија, ме згазија, ме вчупија,

по џепови наредија!
Поминаја девојките, поминаја ме згазија, ме згазија, ме вчупија, поперја ме наредија! Поминаја невестите, поминаја ме згазија, ме згазија, ме вчупија, по перја ме наредија! 
АИФ, касета бр. 3982, с. Радожда, Струшко (2003). Пеат Цара Чочоска (75), Ангелина Грческа (66) и Јорда Скерческа (77) од с. Радожда, Струшко. Снимила, дешифрирала и мелографирала Родна Величковска. Велигденечка песна, во: Р. Величковска Музичките дијалекти..., стр.165, песна број 66.

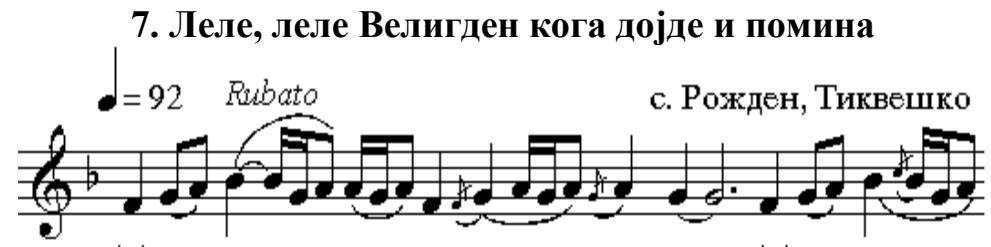

(и) Ле-ле ле - ле Ве - лиг-ден (и) ко-га

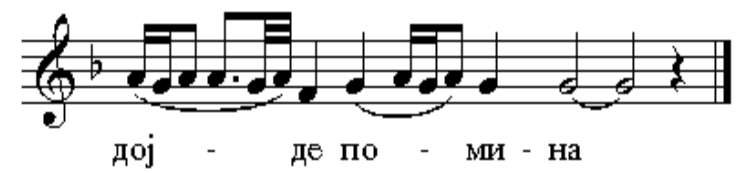

(и) Леле, леле Велигден

(и) кога дојде помина!

ни сос око чкрапна́аме,

Леле, леле Велигден

кога дојдѐ и помина́!

Ни сос рака мана́аме,

ни сос нога тропна́аме!

АИФ м.л. бр.1552, Долни Дисан, Кавадаречко (1970). Пее Петра Трајкова (1933) од с. Рожден, Кавадаречко. Снимил Киро Андонов, дешифрирала и мелографирала Родна Величковска. Во: Р. Величковска, Музичките дијалекти..., стр.174, песна број 64.

\section{8. Калемчице, малемчице}
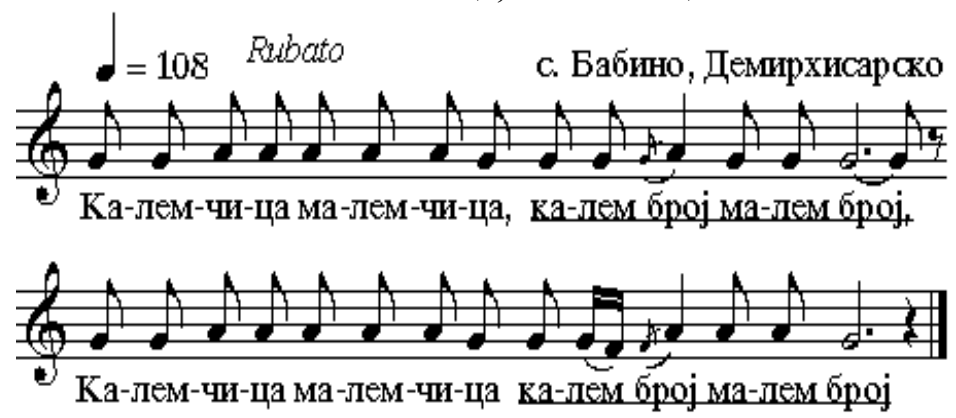

Калемчице, малемчице

Калем број, малем број!

Расцутиле вишни црешни...

Калем број, малем број! 
АИФ м.л. бр. 473, с. Бабино, Демирхисарско (1966 г.). Пее Нове Касаповски. Снимил Ганчо Пајтонџиев, дешифрирала Милка Здравева, мелографирал Михајло Димовски. Во: Р. Величковска, Музичките дијалекти..., стр.158, песна број 55.

\section{9. Сега да видиме која поле била}

I група:

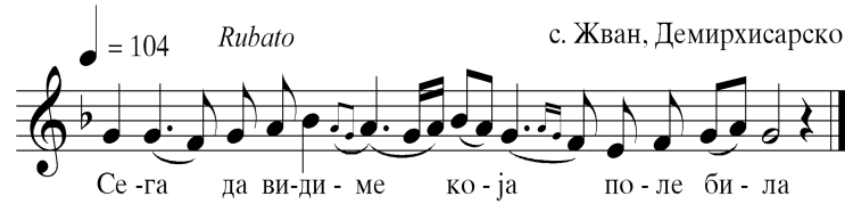

II група:

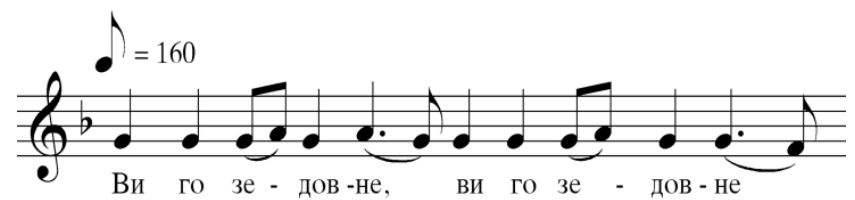

I група:

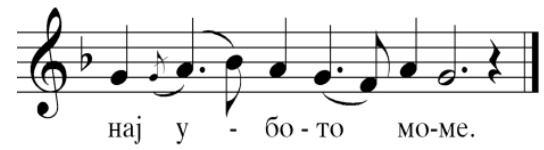

Сега да видиме која поле била, која поле била, која метил пасла, која метил пасла во копривје расла.

Васка поле била во копривје расла.

II група: - - - Ви го зедовне, ви го зедовне најубавото моме!

АИФ м.л. бр. 464, с. Жван, Демирхисарско (1966). Пее Спаса Пејкова, родена 1942 год. Снимил Ганчо Пајтонџиев, дешифрирала Милка Здравева, мелографирал Михајло Димовски. Во: Р. Величковска, Музичките дијалекти..., стр.159, песна брoj 57.

10. Младе́не, Младе́не, Младе́не војво́до

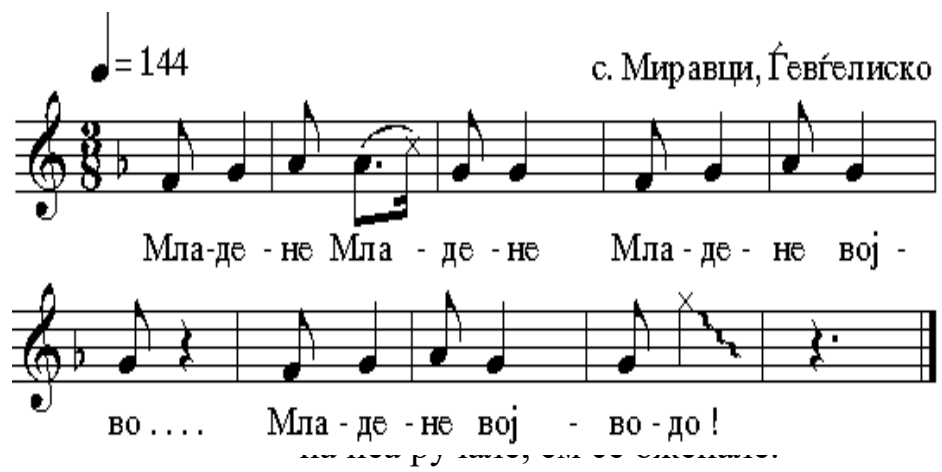


АИФ, м.л. бр. 2709, с. Миравци, Гевгелиско (1979). Пеат Гуна Ташева (1920) и Варвара Ѓорѓиева. Снимил Ѓорѓи Ѓорѓиев, дешифрирала и мелографирала Родна Величковска. Велигденска песна. Се пее на оро додека се игра „Гура Мара“. Се игра во круг. Во: Р. Величковска, Музичките дијалекти..., стр.159, песна број 69.

\section{Прилог Илустрации}

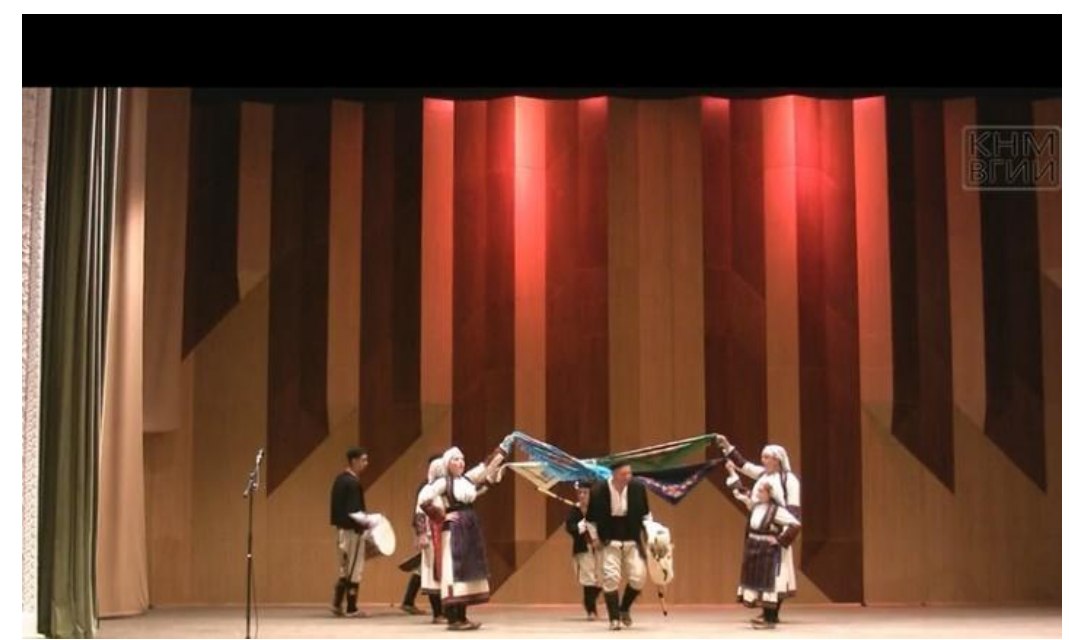

1. Поречката велигденска игра „Каленчица“, во изведба на Вокално-инструменталната група при КУД „, С Септември“ од Македонски Брод, во Воронеж, 16 септември 2015 година.

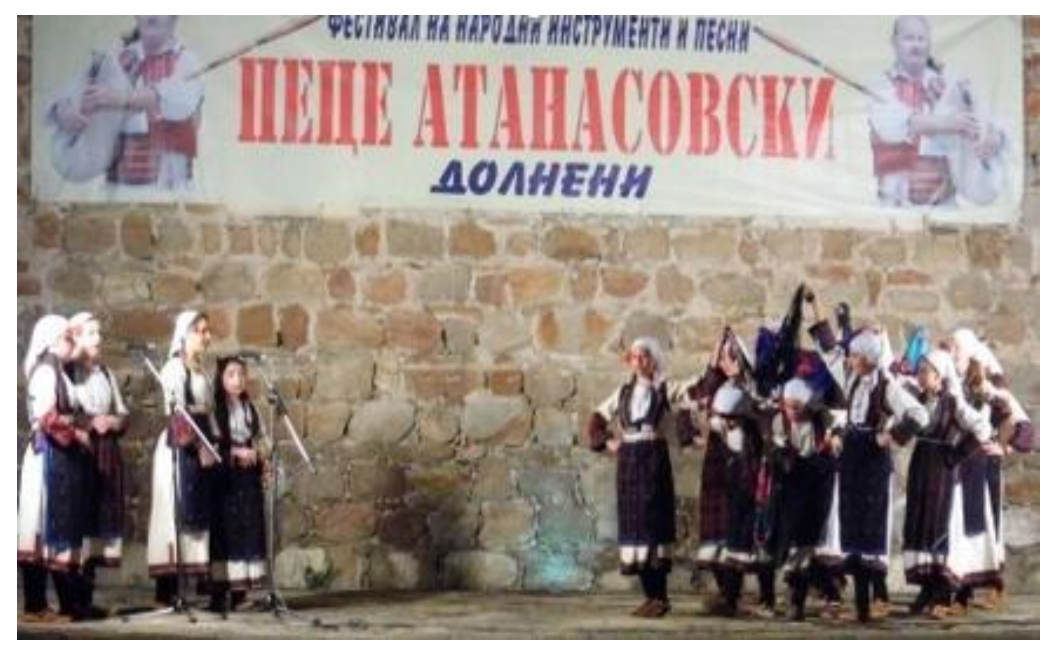

2. Поречката велигденска игра „Каленчица, кален број, мален број“ во изведба на пејачката група при ОУ Дом на култура „Македонски Брод“ - Македонски Брод, ФЕНИП „Пеце Атанасовски“, Долнени, 2016 год. 


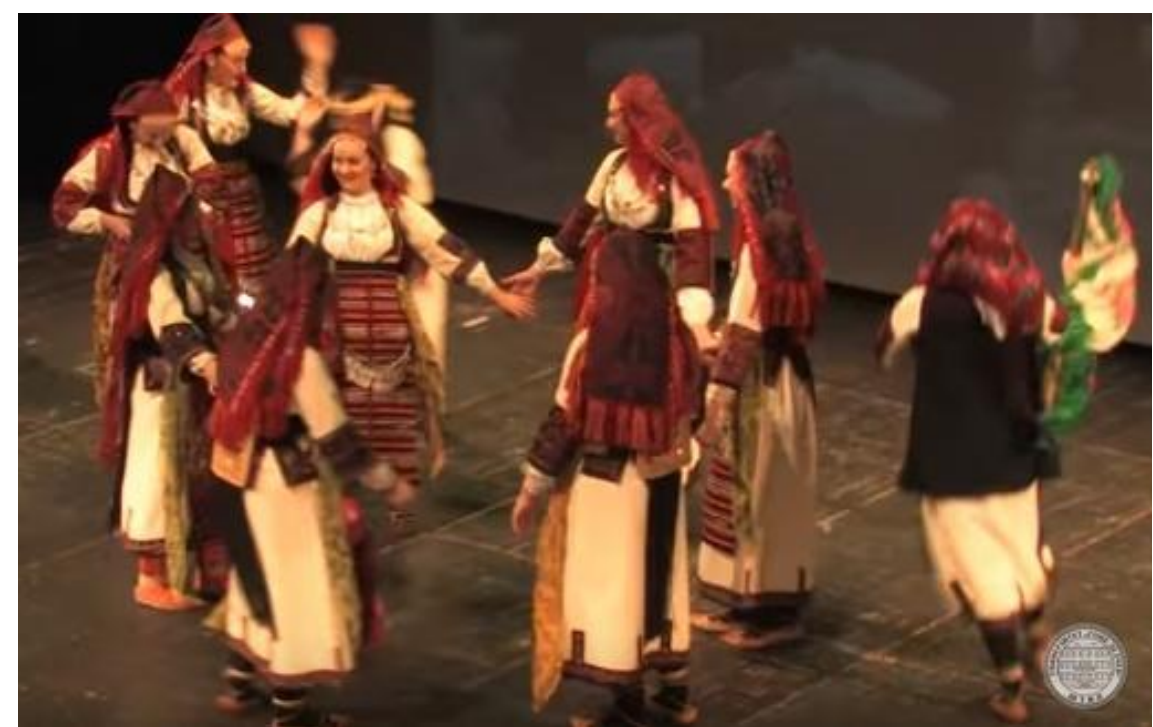

3. Поречката велигденска игра „Змија“

во изведба на Ансамблот „Македонија“, Скопје, 2018 година.

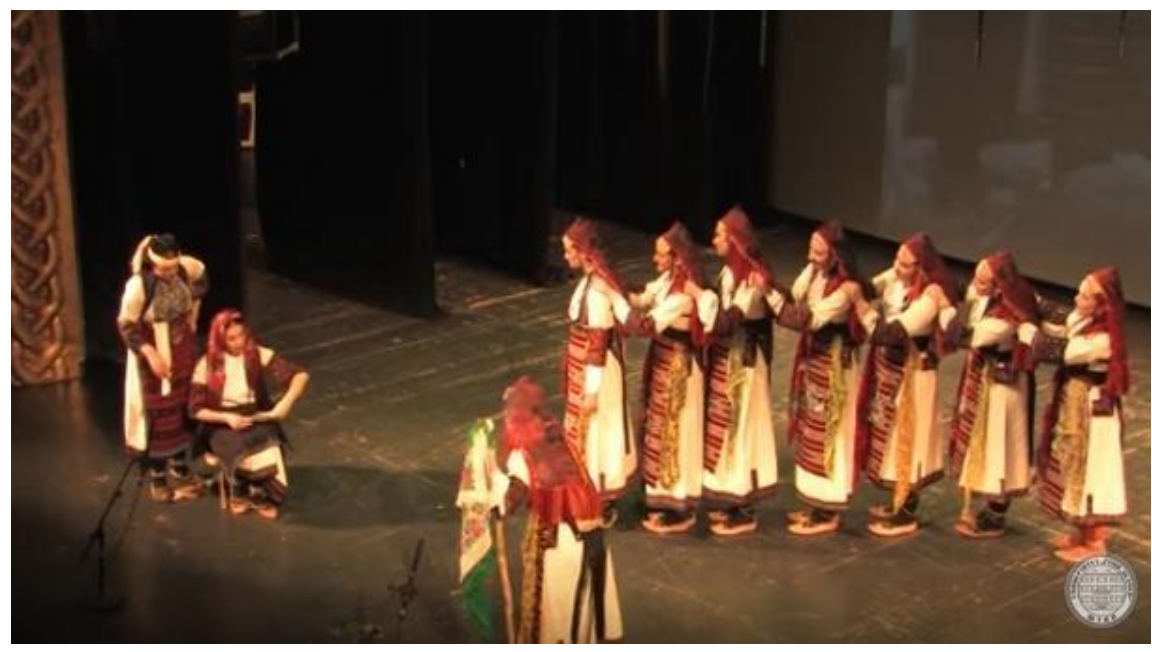

4. Поречката велигденска игра „Маски“

во изведба на Ансамблот „Македонија“, Скопје, 2018 година 